\title{
Arabisk verden splittet af forårsfornemmelser
}

\section{Anders Jerichow}

\section{Den Arabiske Liga er ældre end EU. Dens held til at skabe udvikling og frihed var slået fejl, da 'for- året brød løs'. Nu er Arabien splittet i tre: De rige, de jæune og de fattige - eller de sidste diktaturer, de nye demokratier og de fejlslagne}

Den Arabiske Liga må desperat have søgt efter en grimasse, der ku’ passe, da den norske Nobelkomité besluttede at give årets fredspris til EU.

Såmænd behøvede der ikke være så stor forskel på EU og Den Arabiske Liga. Begge organisationer er grundlagt efter Anden Verdenskrig. Begge er stiftet for at styrke indbyrdes samhandel, begge desuden med sigte på at styrke det politiske samarbejde i hver deres landekreds og begge for at fremme muligheden for fred.

Ganske vist fik ikke så få - en tredjedel - af de arabiske stater først deres fulde selvstændighed omkring 1970, da de hidtidige britiske protektorater Oman, Qatar, Bahrain og de syv bysamfund i det senere selvstændige Forenede Arabiske Emira- ter fik deres frihed fra London.

Men også i EU har en tredjedel af medlemskredsen først oplevet fuld politisk selvstændighed ved Murens fald og endda derefter. Baltikums tre stater - Estland, Letland og Litauen - tjente som Sovjetunionens protektorater, indtil Sovjetunionen brød sammen for tyve år siden. Lande som Slovenien og Kroatien (Kroatien vil efter planen blive optaget som det 28. medlemsland den 1.juli 2013, red.) blev kun selvstændige, da det hidtidige Jugoslavien brød sammen i begyndelsen af i 1990'erne. Og ret beset er det svært at tale om selvstændighed for lande som Tjekkiet, Slovakiet, Polen og DDR, før de slap fri af den kvælende alliance med moskvakommunismen. I det lys har ikke kun den arabiske 
verden, men også Europa og EU haft sit at slås med på selvstændighedens svære vej. Europa har haft sine krige på Balkan og før dét sine sovjetiske interventioner i det daværende Tjekkoslovakiet, sine tyrkiske og græske interventioner i Cypern. Det har forud for EU haft gigantiske genopbygningsopgaver efter Anden Verdenskrig. Det har set Spanien, Portugal og senere Grækenland bryde med diktaturet til fordel for demokrati - og senere staterne i Centraleuropa bryde med den repressive sovjetkommunisme til fordel for demokrati, markedsøkonomi og retssamfund.

Så det er jo ikke, fordi EU-kredsen har fået meget foræret på vejen til at etablere verdens tryggeste og regionalt set rigeste velfærdssamfund.

Men, ja, det er faktisk lykkedes EU - uanset den nuværende krise og bitterhed, navnlig i Grækenland og Spanien - at sikre fred inden for sin egen landekreds. Det er lykkedes at fjerne jerntæppet, soldater og vagttårne fra EU's interne grænser. Det er lykkedes at gennemføre en trods krisen i dag - historisk social og økonomisk harmonisering mellem Nord og Syd, og en tilsvarende er godt på vej mellem Vest og $\emptyset_{\text {st. }}$.

Alt dette i en region, der gjorde det 20. århundrede til et helvede for sig selv med to verdenskrige, diktatur i Øst og Syd, folkemord og en helt enestående ødelæggelse - før EU.

\section{Forliste arabiske drømme}

Den arabiske verden ville være udmærket tjent med samme resultat og har ikke mindre haft brug for fred, udvikling og harmonisering.

Kun syv arabiske samfund (Egypten, Irak, Syrien, Libanon, SaudiArabien, Jordan og Yemen) havde deres selvstændighed ved Ligaens etablering i 1945. Men det lykkedes ret beset de fleste arabiske samfund at opnå national selvstændighed inden 1970 - de fleste fik det allerede i 1950'erne (Libyen, Sudan, Marokko og Tunesien) og 60'erne (Kuwait og Algeriet), før de sidste golfstater fulgte efter omkring 1970. Kun palæstinenserne venter fortsat på uafhængighed, mens Vestsahara modsat de fleste andre skulle miste sin selvstændighed, da Marokko lod dette land invadere i 1975 .

Men de ambitioner om arabisk samarbejde, der var Ligaens fundament, skulle ikke spare de arabiske lande for krige. Kun nogle af krigene handlede om det særlige forhold til den nye stat Israel. Andre krige skulle belaste Egypten, Yemen, Irak, Kuwait, Libyen og Marokko udadtil, ligesom særskilte borgerkrige skulle udmarve samfund som Oman, Libanon, Irak, Sudan, Jordan og Somalia m.fl. indadtil.

Trods drømme om panarabisme og forskellige varianter af arabisk solidaritet er det således ikke lykkedes den arabiske verden at gøre op med sine indre grænser, der næsten over- 
alt er markeret med hegn og mure og et velbevogtet ingenmandsland. Selv i den mest vellykkede samarbejdsblok - de arabiske golfstaters samarbejdsråd, GCC - er grænserne stærkt overvåget; borgere skal have ID-papirer for at rejse på tværs, og GCC-regeringerne stoler ikke nok på hinanden til at fjerne grænsebommene.

De arabiske staters magthavere har eksperimenteret med forskellige udgaver af nationalisme, kommunisme, socialisme og kontrollerede versioner af markedsøkonomi. Også her har markedsøkonomiske tiltag slået planøkonomisk socialisme. Det gælder ikke kun blandt de potentielt rige olielande, hvor de overvejende markedsøkonomiske golfstater har skabt større velfærd for sine borgere end de - gennem mange år planøkonomiske og halvsocialistiske oliestater i Nordafrika som Algeriet og Libyen. Det gælder også blandt de arabiske stater, der fra naturens side er mindre gunstigt stillet; i denne kreds har økonomisk set relativt liberale stater som Libanon og Tunesien klaret sig økonomisk mærkbart bedre end fx det længe planøkonomisk styrede Egypten.

Men da den frustrerede tunesiske ungersvend Mohammed Bouazizi i slutningen af 2010 satte ild til sig selv, udløste han en opstand, som gik på tværs af politiske og økonomiske eksperimenter, republikker og monarkier. Bouazizi vidste ikke, at han satte gang i 'det arabiske forår'.
Han var blot frustreret over arbejdsløshed, dårlig økonomi og fornemmelsen af at være et offer for politisk og økonomisk misrøgt.

En, to, tre begyndte et oprør at brede sig over den arabiske verden. I Tunesien valgte diktatoren Ben Ali at flygte til Saudi-Arabien. I Egypten erstattede diktatoren Hosni Mubarak præsidentpaladset med en sommerbolig i Sinai, måske efter at militærets ledelse - hans makkere i diktaturet - havde opgivet at beskytte ham mod de vrede folkemasser på Tahrir-pladsen, Frihedspladsen, i Cairo. I Bahrain samlede hen ved halvdelen af befolkningen sig på rundkørslen omkring Perlemonumentet, tegnet af den danske arkitekt Ib Lyngholm, for at kræve demokrati. I Yemen lod diktatoren Saleh sig presse fra magten til fordel for sin reformorienterede vicepræsident. I Libyen blev diktatoren Moammar Gaddafi væltet ved et væbnet oprør, støttet fra luften af europæiske stater - deriblandt Danmark - i samarbejde med to arabiske, dels Qatar, dels De Forende Arabiske Emirater.

Og mens disse linjer skrives, forsøger den syriske diktator, Bashar alAssad, at bombe byer og landsbyer for at genvinde om ikke sit folks kærlighed, for det har næppe nogensinde elsket ham, så i hvert fald genvinde folkets frygt og respekt. Hverken den arabiske verden eller den vestlige regner ham længere for en del af Syriens fremtid, kun en år- 
sag til Syriens blodige ulykke.

$\mathrm{Nu}$ hvor EU modtager Nobels fredspris for sit bidrag til udvikling, harmonisering og fred i Europa, oplever den arabiske verden modsat at være skæbnesvangert delt i de rige, de jævne og de fattige. Og Den Arabiske Liga er lammet.

Ligaen har opgivet at handle $\mathrm{i}$ enighed. Den har været ude af stand til at redde hverken arabiske befolkninger, som beder om frihed, eller arabiske regeringer, som klamrer sig til magten.

Ligaen opdagede knapt, at Ben Ali var detroniseret i Tunesien, før han sad i flyet til Saudi-Arabien. Den opgav at have en holdning til de dramatiske demonstrationer i Bahrain og Cairo, Ligaens hjemsted. Den magtede ikke at formidle den senere overgangsløsning i Yemen. Den suspenderede Libyens medlemskab af Ligaen, da Gaddafi begyndte at bombe sit eget folk, men kunne kun se passivt til, at Qatar og Emiraterne i hvert fald politisk støttede de NATO-magter, som satte fly ind for at standse Gaddafis luftvåben. Og Ligaen har under Syriens revolution atter været ude af stand til at formulere en holdning, der kan samle opbakning fra de arabiske staters gamle og nye regeringer. Så Ligaen - de arabiske staters samarbejdsforum er lammet.

De rige, de jævne og de fattige kan også karakteriseres på anden vis - som de sidste diktaturer, de nye demokratier og de fejlslagne. Eller:
Kongedømmerne, republikkerne og de funktionsramte.

\section{Fattige og fejlslagne}

Mens EU de seneste to år har holdt det ene krisemøde efter det andet for regeringschefer og for finansministre for at finde løsninger på den økonomiske nedsmeltning i Sydeuropa, har Den Arabiske Liga ikke holdt et eneste krisemøde for de fattige, fejlslagte og funktionsramte medlemmer: Somalia, Djibouti, Sudan og reelt Yemen og Palæstina.

På enhver international skala befinder disse stater sig i bunden. Deres borgere hører til verdens fattigste og lider af både mangel på sundhed, velfærd og uddannelse. De fem stater har også dét til fælles, at de lider af manglende sammenhængskraft; de savner retssikkerhed, de er ramt af intern splittelse, de er plaget af korruption, de har en effektiv regering til gode, og deres magthavere står ikke til ansvar.

Internationalt set er disse fem stater kilde til bekymring. NATO-fartøjer patruljerer ud for Somalia og Djibouti for at forsvare den internationale skibstrafik mod pirater. Afrikanske styrker er indsat i Somalia. FN forsøger ihærdigt at hjælpe de palæstinensiske områder mod økonomisk og politisk nedsmeltning. USA jagter al-Qaeda-aktivister i Yemen, hvor lokale klanledere og militsfolk udfordrer den centrale regering. Men på den fælles arabiske 
dagsorden giver de fem ildestedte samfund ikke anledning til hverken hektisk diplomati, krisestemte topmøder eller heftige nødplaner.

Én af disse mere eller mindre fejlslagne stater, Yemen, har i årevis døjet med stærke lokale klanledere, som i flere tilfælde har rådet over regulære hære, udrustet med kampvogne og heftige våben. $\mathrm{Og}$ den nu afsatte diktator, Saleh, satte gerne militære styrker ind mod oprørere og rebelske klanmilitser. Han havde ingensinde haft kontrol med hele Yemen og fik det heller ikke. En dag var han ved at miste livet ved en bombeeksplosion i en moske og måtte opgive at vende tilbage til magten efter et længere hospitalsophold i Saudi-Arabien.

Palæstinenserne har stadig en betydelig placering på den politiske dagsorden. Men det er længe siden, at Palæstina har været prioriteret af andre arabiske stater og regeringer. I stedet er Palæstina og de øvrige mere eller mindre fejlslagne arabiske stater overladt til sig selv. Det gælder også Vestsahara, der har været besat af Marokko siden 1975 .

\section{Republikker ramt først}

Mohammed Bouazizi, den tunesiske selvantænder, var usædvanligt handlekraftig i sin frustration. Men hans frustration var ikke usædvanlig. Til gengæld var det overraskende, at hans død kom til at antænde en vrede så omfattende, at den kunne væl- te ét at den arabiske verdens mest forstenede diktaturer.

Tunesien havde kendt til gadeprotester før, mest kendt måske under den såkaldte brødopstand midt $\mathrm{i}$ 1980'erne, hvor indbyggerne i Tunis by gik på gaden for at protestere, da det daværende Bourguiba-regime satte prisen i vejret på semoulje, som er nødvendigt for at lave nationalretten cous-cous. Flere end 100 mennesker blev dræbt af politiet; de blev begravet i ly af natten, fordi sikkerhedstjenesten var bange for demonstrationer.

Allerede dengang brugte de tunesiske sikkerhedstjenester tortur i deres undertrykkelse af dissidenter. Ikke så få oplevede at blive torteret $\mathrm{i}$ cellerne under Indenrigsministeriet på det fornemme hovedstrøg i Tunis By, hvor den måske mest magtfulde minister holdt til øverst oppe.

Diktatoren Ben Ali blev så chokeret over de folkelige protester, at han tog flugten til Saudi-Arabien, da Frankrig afviste at tage imod ham.

Den egyptiske diktator, Hosni Mubarak, var øjensynlig lige så chokeret, da Tahrir-pladsen i Cairo blev fyldt med egyptere, der krævede politisk frihed og dét med en sådan vrede, at de i ugevis blev stående, selv om politiet og civile bøller i politiets tjeneste slog omkring 850 mennesker ihjel.

Mubarak havde aldrig været kendt som noget intellektuelt lys, og i dag er det stadig uvist, om han selv valgte at tage i 'sommerhus' i Sinai, eller 
om hans kammerater i militærets ledelse sendte ham af sted for selv at bevare magten. Under alle omstændigheder var resultatet, at militæret forsøgte at fastholde diktaturet ved på den ene side at love demokrati, på den anden side at lade en junta, 'SCAF', operere, som om intet var hændt. Militæret har regulært kontrollen med 40 pct. af den egyptiske økonomi, og den har militæret næppe til hensigt hverken at opgive eller at give offentligheden, medier eller parlamentet indblik i.

Begge samfund, både Tunesien og i Egypten, havde før revolutionen indrettet sig som 'republikker' med såkaldt folkevalgte parlamenter og folkevalgte præsidenter, skønt folket $\mathrm{i}$ ingen af disse stater reelt havde mulighed for at vælge andre end de kandidater, som regimerne udpegede for dem.

I begge samfund har Det Muslimske Broderskabs partier, som var forbudt under diktaturet, vundet de første demokratiske valg - sandsynligvis som resultat af et mangeårigt socialt engagement på områder, hvor staten under diktaturet ikke slog til. Det har nu givet dem regeringsmagten, men også ansvaret for en voldsom ungdomsarbejdsløshed, et dårligt investeringsklima, et korrupt statsapparat og en anseelig opgave med at rette op på en elendig offentlig administration.

Både i Tunesien og Egypten er de blevet stillet over for den udfordring at udforme forslag til helt nye forfat- ninger, der skal afklare forholdet mellem stat og religion, mænd og kvinder, sikkerhedsapparat og menneskerettigheder, parlament og militær - og så videre.

\section{Fra Gaddafi til Assad}

Libyere stod parat til at videreføre de arabiske revolutioner for at slippe af med fire årtiers hårfagre diktator, Moammar Gaddafi. Han havde aldrig besværet sig med at indrette så meget som et officielt parlamentet, men snarere gjort en dyd ud af såkaldte revolutionære komiteer spredt over hele lande.

Gaddafi var ikke til sinds at lade sig overrumple. Da oprøret brød ud, gav han hurtigt og skånselsløst sit militær og luftvåben til opgave at slå opstanden ned. Det var dog mere, end Den Arabiske Ligas flertal ville acceptere - Gaddafi blev suspenderet fra Ligaens topmøder, og to Liga-lande, Qatar og De Forenede Arabiske Emirater, besluttede sammen med NATO-kredsen - med godkendelse fra FN's sikkerhedsråd - at sætte luftmagt ind for at beskytte libyerne fra luften. Det afholdt ikke Gaddafi fra at forsøge at bombardere sig til folkelig accept.

Men i sidste ende var Gaddafis diktatur færdigt. Han forsøgte at flygte, men blev meget ydmygende afsløret på sin flugt - i et åbent kloakrør uden for byen Sirte - og 'henrettet' af vrede oprørere ved højlys dag.

På kun et halvt år var magthaver- 
ne i tre hårdkogte diktaturer i den arabiske verden faldet - deriblandt den mangeårige diktator for det mest folkerige og traditionelt ledende arabiske samfund og hjemstedet for Den Arabiske Liga, Egypten.

Syrerne er nu i voksende tal på barrikaderne for at føre den arabiske opstand videre. Også deres diktator, Bashar al-Assad - officielt folkevalgt præsident for en 'republik', skønt aldrig udsat for modkandidater - blev suspenderet fra Den Arabiske Liga.

Men Ligaen var ingenlunde enig om at tage afstand fra den magtfulde Assad, som truede både sit eget samfund og sine naboer med opløsning og borgerkrig. Først i november havde Assad ansvaret for drab på flere end 35.000 mennesker og hævdede endda, at han stadig kunne genvinde såvel magten som sit folks kærlighed.

\section{Kongedømmer tror sig immune}

Hvis Saudi-Arabien og de olierige monarkier ved Den Persiske Golf skulle tages for pålydende, repræsenterer kongedømmerne en særlig tradition med iboende arabisk autencitet og garanti for harmoni. Kongedømmerne har ifølge sig selv en tradition for at tage befolkningerne på råd. Det skulle gøre demonstrationer og oprør helt unødvendige.

Sådan lyder i hvert fald det saudiske omkvæd. Men den mindste
GCC-stat, Bahrain, har både udhulet påstanden om, at monarkiernes befolkninger ikke ønsker demokrati og alle påstande om, at kongedømmerne kan regne med at nyde deres befolkningers opbakning.

For at gøre en lang historie kort: Bahrain havde oplevet folkelige krav om demokrati før. Og i foråret 2011 gik hen ved halvdelen af den bahrainske befolkning igen på gaderne for at kræve ret til at stille magthavere til ansvar. Næsten 300.000 bahrainere samledes omkring det berømte perlemonument for at få politisk frihed. Og magthaveren, Hamad alKhalifa - der udråbte sig selv til konge, da han åbenbart var træt af at være emir - satte militæret ind for at knuse opstanden.

Det gjorde han effektivt og med opbakning af 1.000 saudiske tropper. Men ikke effektivt nok. Selv om de fleste af systemkritikernes ledere - med dansk-bahraineren Abdulhadi al-Khawaja i spidsen - blev arresteret, torteret og idømt lange fængselsstraffe, fortsatte protesterne mod Khalifa-familiens magt.

Og Bahrain var ikke ene om at forbyde politiske demonstrationer i 2012. Også Kuwait, der her i efteråret har oplevet vældige protester mod Sabah-familiens enerådende magt, har forbudt demonstrationer - lige som Saudi-Arabiens kongefamilie, der nogenlunde samtidig lod sine sikkerhedsstyrker slå hårdt ned på systemkritikere, især i den olierige østlige provins. 
Alle de seks arabiske golfstater har - især efter Kuwait-krigen 1990/91 indrettet en slags parlamenter eller rådgivende forsamlinger. De har dog alle til fælles, at ingen af forsamlingerne kan vedtage nye love uden accept fra kongefamilierne, ligesom de har til fælles, at kongefamilierne ikke står til ansvar for deres borgere og selv har beholdt overvågningen og kontrollen med dele af den givtige olieproduktion.

Ingen af de seks GCC-stater har frit valgte parlamenter med stemmeret til alle borgere og med ret til fri organisering eller partidannelse. Ingen af dem sikrer sine borgeres menneskerettigheder. Ingen af dem har lighed mellem mænd og kvinder.

Til gengæld har de seks arabiske golfstater noget, de fleste andre arabiske stater savner - ikke kun de mere eller mindre fejlslagne, men også republikkerne. Golfstaterne er ganske velbeslåede og overlader alle i stor udstrækning en stor del af landenes arbejdsopgaver til udenlandske migranter. Til gengæld forsøger de at forkæle egne arabiske statsborgere med gratis sundhed, uddannelse, billige boliger m.m., og de har efter 'det arabiske forår' i andre stater forsøgt at komme deres egne borgere i møde med sociale investeringer snarere end politiske indrømmelser.

I Bahrain har oprøret vist, dels at rådgivende forsamlinger aldrig kan gøre det ud for politisk frihed og ret til at stille magthavere til ansvar, dels at selv knap 100 dræbte, flere tusinde arresterede og fyrede og mange udsat for tortur ikke har fået kravet om frihed til at lægge sig.

\section{Diktatorer på lånt tid}

Der har været andre arabiske forår. Bahrain har kendt til oprør og folkelige demonstrationer for demokrati og frihed helt tilbage i 1975, og i Algeriet var det et folkeligt oprør, der fik det hidtidige FNL-regime til at acceptere udskrivelsen af et frit valg i 1991 - men under anden valgrunde kuppede militæret magten og fastholdt den. I den efterfølgende borgerkrig kostede det hen ved 140.000 algeriere livet.

De opstande, der nu bølger over den arabiske verden, burde heller ikke have været overraskende, for kloge folk som den egyptiske forsker Saad Eddin Ibrahim, den syriske filosof Sadek Jalal al-Azm og den jordansk-palæstinensiske essayist Ramy Khoury havde i årevis varslet, at låget på den arabiske verdens trykkoger en dag ville ryge af. Og årsagen burde heller ikke have overrasket nogen som helst. Da FN's udviklingsprogram, UNDP, i 2004 bad 22 store arabiske økonomer kigge arabisk udvikling efter i sømmene, nåede de frem til, at deres verden havde eklatante underskud på frihed, lighed og viden.

Deres analyser under fællestitlen 'Arab Human Development Report' 
var lige så tørre, som de var nådesløse i kritikken af magthavernes misrøgt af deres regions udvikling. Sagen var enkel: De arabiske samfund kunne have opnået en langt større udvikling. De havde spildt ressourcer, spildt tid, spildt borgernes muligheder.

Den arabiske verden led ifølge $\varnothing$ konomerne under manglende frihed til at organisere sig fagligt, erhvervsmæssigt og politisk. Den led af manglende lighed mellem rig og fattig, mellem nogle af verdens rigeste og fattigste samfund og mellem mænd og kvinder. Og Arabien led af manglende inddragelse i udvikling og udveksling af ny viden på tværs af grænser.

Men hvorfor? Af kulturelle grunde? Nej. Af religiøse grunde? Heller ikke? Hvorfor så? Fordi totalitære herskere i årtier havde holdt de ara- biske samfund under et repressivt låg - som før eller siden måtte eksplodere. Sig så ikke, at de arabiske revolutioner - 'det arabiske forår' var overraskende, nyt eller uventet.

$\mathrm{Nu}$ er låget sprængt af. Mellem$ø$ sten og Nordafrika befinder sig i en vældig forvandling, der har delt det arabiske samfund i tre: de nye demokratier, de sidste diktaturer og de håbløst fejlslagne. Men det var kun første halvleg. Før eller siden vil alle arabere kræve politisk frihed, også til at stille deres magthavere til ansvar.

Magthavernes nervøsitet afslører, at de har forstået signalet. Hver eneste diktator - hvad enten han kalder sig præsident eller konge - regerer på lånt tid.

Anders Jerichow er seniorkorrespondent ved Politiken. 